УДК $338.47+338.14$

DOI: $10.25140 / 2411-5215-2020-3(23)-26-32$

Олена Парубеиь

\title{
ДОСЛІДЖЕННЯ ВПЛИВУ КОРОНАКРИЗИ НА СТАН ТРАНСПОРТНОГО СЕКТОРУ УКРАЇНИ
}

\author{
Елена Парубец \\ ИССЛЕДОВАНИЕ ВЛИЯНИЯ КОРОНАКРИЗИСА \\ НА СОСТОЯНИЕ ТРАНСПОРТНОГО СЕКТОРА УКРАИНЫ
}

Olena Parubets

\section{STUDY OF THE INFLUENCE OF THE CORONA CRISIS ON THE CONDITION OF THE TRANSPORT SECTOR OF UKRAINE}

У статті проведено аналіз впливу коронакризи на показники діяльності транспортного сектору України. Виявлено, щзо значне падіння обсягу перевезень спостерігається на пасажирському транспорті, який безпосередньо підпадає під міжнародні обмеження руху пасажирів. Встановлено, що в умовах пандемії найбільше зменшення обсягів перевезення вантажів спостерігається на автомобільному, річковому й морському транспорті. Серед пасажсирського транспорту найбільш постраждалим є авіаційний. Досліджено прогнозні оцінки міжнародних транспортних організацій стосовно стану та перспектив відновлення діяльності світового транспорту. Запропоновано заходи щзодо відновлення ефективного функиіонування транспортного сектору Украӥни, головними з-поміж яких визначено необхідність надання державної фінансової, правової, інформачійної підтримки, а також різноманітних стимулів $і$ преференцій з боку органів місиевого самоврядування.

Ключові слова: транспортний сектор; фінансування; державна підтримка; коронакриза; проблеми; обсяг перевезень; доходи; розвиток.

Табл.: 3. Бібл.: 15.

В статье проведен анализ влияния коронакризиса на показатели деятельности транспортного сектора Украины. Выявлено, что значительное падение объема перевозок наблюдается на пассажсирском транспорте, который непосредственно подпадает под международные ограничения движения пассажиров. Установлено, что в условиях пандемии наибольшее уменьшение объемов перевозки грузов наблюдается на автомобильном, речном и морском транспорте. Среди пассажсирского транспорта наиболее пострадавшим является авиачионный. Исследовано прогнозные оценки международных транспортных организаций о состоянии и перспективах возобновления деятельности мирового транспорта. Предложены меры по восстановлению эффективного функиионирования транспортного сектора Украины, главными из которых определена необходимость предоставления государственной финансовой, правовой, информационной поддержки, а также различных стимулов и преферениий со стороны органов местного самоуправления

Ключевые слова: транспортный сектор; финансирование; государственная поддержка; коронакризис; проблемы; объем перевозок; доходы; развитие.

Табл.: 3. Библ.: 15

The article analyzes the impact of the Corona Crisis on the performance of the transport sector of Ukraine. It has been revealed a significant decline in carriage of passengers, which is directly subject to international restrictions on passenger traffic. It has been established that in the conditions of the pandemic, the greatest decrease in volumes of freight carriage is observed on automobile, river, and sea transport. Among passenger transport, aviation is the most affected. The forecast estimations of the international transport organizations concerning condition and prospects of restoration of activity of world transport have been investigated. Measures to restore the effective functioning of the transport sector of Ukraine have been proposed; the main of them are the following: the need to provide state financial, legal, and informational support, as well as various incentives and preferences from local governments.

Keywords: transport sector; financing; state support; Corona Crisis; problems; volume of carriage; incomes; development.

Table: 3. References: 15

JEL Classification: L91; E65

Постановка проблеми. Вплив коронакризи негативно позначився на діяльності багатьох секторів вітчизняної економіки, зокрема транспортного. Закриття державних кордонів, зменшення обсягів зовнішньоекономічних операцій призвели до порушення ланцюгу транспортно-логістичних зв’язків як на вітчизняному, так і на міжнародному рівнях i, як наслідок, спричинили зниження обсягів вантажних і пасажирських перевезень та фінансових результатів діяльності транспортних підприємств. Друга хвиля пандемії також обмежила рух різних видів транспорту, особливо пасажирського, як у внутрішньому, так і міжнародному сполученнях. В умовах невизначеності соціальноекономічної ситуації як в Україні, так і у світі, складно планувати та прогнозувати пока- 
ГАЛУЗЕВИЙ АСПЕКТ РОЗВИТКУ НАЦІОНАЛЬНОГО ГОСПОДАРСТВА

зники діяльності й перспективи розвитку транспортного сектору. У зв'язку з цим першочерговим завданням є проведення постійного моніторингу змін, що відбуваються у внутрішньому і зовнішньому середовищі, а також на вітчизняному і міжнародному транспортних ринках для розуміння розвитку процесів, пов'язаних 3 коронакризою, та своєчасного виявлення і ефективного управління різноманітними ризиками, що негативно впливають на стан і перспективи функціонування транспортного сектору України.

Аналіз останніх досліджень і публікацій. Питання функціонування і відновлення діяльності транспорту в умовах пандемії набувають особливої актуальності та стають предметом дослідження багатьох вітчизняних і закордонних учених.

Є. Дженеліус та Л. Метсон [14] зазначають, що соціальні потрясіння у XXI сторіччі можуть бути абсолютно несподіваними, і швидке глобальне поширення COVID-19, частково, пояснюється надзвичайним рівнем мобільності, яку пропонує сучасна транспортна система. Більшість країн намагалися зменшити поширення коронавірусу шляхом закриття кордонів та обмеження мобільності як на місцевому, так і на глобальному рівні, що призвело до різкого скорочення попиту на пасажирські перевезення, а потім відповідної і до зменшення їх пропозиції. Як відповідь на це, набули значного поширення віртуальні контакти при здійсненні підприємницької діяльності. У зв'язку з цим існує реальна загроза того, що з часом звичка до віртуального спілкування залишиться надовго, що, у свою чергу, призведе до зниження попиту на пасажирські перевезення і в подальшому.

A. Коел [15] вказує на те, що пандемія COVID-19 змусила багато країн зазнати безпрецедентно експансивного блокування, що призвело до майже зупинки міських транспортних систем. Міста після COVID-19 відчувають стійке падіння попиту на міські перевезення. На прикладі густонаселених країн із середнім рівнем доходу автором пропонується перехід до інвестування в інфраструктуру, орієнтовану на активні режими подорожей, що здійснюються на велосипедному транспорті. Автор наголошує на необхідність підтримки громадського транспорту, як що він забезпечує мобільність для осіб з обмеженою рухливістю, буферну систему на випадок екстремальних погодних умов та створює нові робочі місця. Для вирішення проблем у сфері громадського транспорту в умовах пандемії пропонується використовувати системний підхід, який передбачає максимізацію соціальної вигоди, покращення ситуації у сфері охорони здоров'я, довкілля тощо. Також автор зосереджує увагу на тому, що пандемія COVID-19 обмежує можливість досягнення низки цілей сталого розвитку Організації Об'єднаних Націй стосовно розвитку транспорту, що потребує проведення подальших досліджень у цьому напряму.

C. Чаі [13], досліджуючи вплив пандемії на міжнародну торгівлю, вважає, що урядам країн необхідно звертати увагу на розвиток транспортної інфраструктури, що дозволить зовнішньоторговельним компаніям своєчасно впорядковувати замовлення та встановлювати довгострокові та стабільні відносини між постачальниками і споживачами.

Автори роботи [4] зосереджують свою увагу на дослідженні розвитку транспортної логістики в умовах пандемії, спричиненої поширенням коронавірусної інфекції. Серед запропонованих напрямів розвитку транспортної логістики в умовах пандемії пріоритетними, на думку авторів, є об'єднання транспортно-логістичних компаній, розвиток аутсорсингу, впровадження новітніх IT-технологій, розширення сфери застосування безконтактної кур'єрської доставки, остаточного переходу логістичних заходів в онлайн-формат.

Досліджуючи питання управління кризовими ситуаціями в умовах пандемії, автори роботи [3] зазначають, що найбільший негативний вплив коронакриза спричинила саме на діяльність авіаційного транспорту, зумовивши високий ступінь вірогідності банкрутства авіакомпаній. Автори пропонують впроваджувати у практику діяльності компаній, що зазнали економічних втрат унаслідок поширення коронакризи, сучасні інструменти антикризового управління. 
Виділення недосліджених частин загальної проблеми. У більшості наукових праць досліджуються питання впливу коронакризи на стан окремих видів транспорту. Однак в умовах невизначеності й ризику, спричинених поширенням коронавірусної інфекції, необхідно шукати шляхи виходу із ситуації, що склалася, не в розрізі окремих видів транспорту, а в напрямі перспектив розвитку їх взаємодії, формування мережевих транспортних структур з метою підвищення конкурентоспроможності транспортного сектору економіки України, що потребує проведення подальших наукових розробок у цьому напрямі.

Мета статті полягає в дослідженні впливу коронакризи на стан транспортного сектору України й обгрунтуванні заходів, спрямованих на відновлення його стабільного функціонування і найшвидшого досягнення докризових показників діяльності.

Виклад основного матеріалу. Для того щоб зрозуміти вплив пандемії на стан вітчизняного і світового транспорту, необхідно спочатку зупинитися на прогнозах розвитку та аналізі основних показників їхньої діяльності. Прогнозні оцінки міжнародних організацій стосовно перспектив розвитку світового транспорту, які необхідно враховувати при плануванні показників діяльності транспортного сектору України, наведені в табл. 1.

Таблиця 1

\section{Прогнози міжнародних транспортних організащій стосовно розвитку світового транспорту}

\begin{tabular}{|l|l|}
\hline \multicolumn{1}{|c|}{ Назва міжнародної організації } \\
\hline $\begin{array}{l}\text { Міжнародний транспортний форум } \\
\text { ОССР }\end{array}$ & $\begin{array}{l}\text { Піжнародний вантажообіг у } 2020 \text { р. у середньому знизиться до } \\
40 \% \text { в порівнянні 3 показниками 2019 р. }\end{array}$ \\
\hline $\begin{array}{l}\text { Міжнародний союз автомобільного } \\
\text { транспорту }\end{array}$ & $\begin{array}{l}\text { У } 2020 \text { р. доходи вантажного транспорту знизяться на 550 млрд } \\
\text { єро, або 18\%. Пасажирський транспорт європейських країн } \\
\text { зазнає зменшення доходів на рівні 57 \%. }\end{array}$ \\
\hline $\begin{array}{l}\text { Міжнародна асоціація повітряного } \\
\text { транспорту }\end{array}$ & $\begin{array}{l}\text { Суттєве скорочення обсягів пасажиропотоку в розрізі авіаційно- } \\
\text { го транспорту становитиме від 59 до 66 \% запланованих показ- } \\
\text { ників, при цьому сукупні витрати міжнародних авіакомпаній } \\
\text { становитимуть 237-260 млрд дол. США }\end{array}$ \\
\hline
\end{tabular}

Джерело: складено на основі [5; 6; 7].

За оцінками багатьох міжнародних транспортних організацій та експертів за умови подолання коронавірусної інфекції відновлення роботи транспортного сектору до докризових показників може зайняти близько двох років.

Призупинення функціонування у звичному режимі підприємств багатьох видів економічної діяльності у зв'язку з карантинними обмеженнями спричинило відповідне зменшення обсягів перевезень вантажів усіма видами транспорту в Україні (табл. 2).

Таблиця 2

Обсяг перевезення вантажів за січень-вересень 2018-2020 рр., млн т

\begin{tabular}{|c|c|c|c|}
\hline \multirow{2}{*}{ Вид транспорту } & \multicolumn{3}{|c|}{ Рік } \\
\hline & 2018 & 2019 & 2020 \\
\hline Залізничний & 240,1 & 234,2 & 223,1 \\
\hline Автомобільний & 99,9 & 141,5 & 108,3 \\
\hline з них у міжнародному сполученні & 5,4 & 8,0 & 6,0 \\
\hline Річковий & 2,8 & 2,9 & 2,5 \\
\hline з них у міжнародному сполученні & 1,0 & 1,1 & 0,8 \\
\hline Морський & 1,4 & 1,6 & 1,3 \\
\hline з них у міжнародному сполученні & 0,9 & 0,8 & 0,7 \\
\hline Трубопровідний & 80,5 & 82,1 & 71,2 \\
\hline Авіаційний & 0,1 & 0,1 & 0,1 \\
\hline
\end{tabular}

Джерело: складено на основі [2].

Як видно $з$ наведених у табл. 2 даних, зниження обсягів перевезення вантажів у січні-вересні 2020 р. у порівнянні з аналогічним періодом 2019 р. становили на залізничному транспорті 4,7\%, автомобільному - 23,4\%, річковому - $13,8 \%$, морському $18,8 \%$, трубопровідному - 13,3 \%, авіаційному - 9,4 \%. 
ГАЛУЗЕВИЙ АСПЕКТ РОЗВИТКУ НАЦІОНАЛЬНОГО ГОСПОДАРСТВА

Аналіз обсягів перевезення пасажирів за видами транспорту наведено в таблиці 3.

Таблиця 3

Обсяг перевезення пасажирів за січень-вересень 2018-2020 рр., млн чол.

\begin{tabular}{|l|c|c|c|}
\hline \multirow{2}{*}{ Вид транспорту } & \multicolumn{3}{c|}{ Рік } \\
\cline { 2 - 4 } & $\mathbf{2 0 1 8}$ & $\mathbf{2 0 1 9}$ & $\mathbf{2 0 2 0}$ \\
\hline Залізничний & 118,8 & 117,8 & 51,7 \\
\hline Автомобільний & 1427,9 & 1351,9 & 804,9 \\
\hline Водний & 0,5 & 0,6 & 0,2 \\
\hline Авіаційний & 9,7 & 10,7 & 3,8 \\
\hline Трамвайний & 505,3 & 459,8 & 314,7 \\
\hline Тролейбусний & 761,0 & 699,7 & 428,6 \\
\hline Метрополітенівський & 534,5 & 526,2 & 295,2 \\
\hline
\end{tabular}

Джерело: складено на основі [2].

Загальний обсяг перевезення пасажирів за період, що аналізується, у 2020 р. знизився на $40 \%$ в порівнянні з аналогічним періодом 2019 р. У розрізі окремих видів транспорту зменшення обсягу перевезень пасажирів за зазначений період становило:

- залізничний транспорт - 56,1\%;

- автомобільний транспорт - 40,5\% ;

- водний транспорт - 59,5\%;

- авіаційний транспорт - 64,6\%;

- міський транспорт - 38,1 \%, зокрема трамвайний - 31,6 \%; тролейбусний $-38,7$ \%; метрополітенівський $-43,9 \%$.

3 огляду на наведені дані можна зробити висновок, що негативний вплив коронакризи найбільш відчутний був саме на пасажирському транспорті, особливо на авіаційному. Така ситуація пояснюється тим, що впроваджені міжнародні обмеження більше стосуються перевезення саме пасажирів. При цьому треба враховувати той факт, що перевезення вантажів авіаційним транспортом здійснюється переважно пасажирськими літаками, що в умовах обмеження внутрішніх і міжнародних авіасполучень спричиняє зменшення вантажообігу та зростання вартості авіафрахту.

Зменшення обсягу перевезень вантажів i, особливо, пасажирів на всіх видах транспорту спричинило виникнення нових і загострення старих проблем. Однією серед системних проблем у діяльності вантажного й пасажирського транспорту є значний ступінь зношення основних засобів, а відповідно, і низький рівень якості транспортних послуг. За підсумками 2019 р. ступінь зношення основних засобів на наземному і трубопровідному транспорті становив 59,2 \%, на водному - 27 \%, авіаційному - 33,0 \%. Наприклад, тільки на залізничному транспорті найбільшу питому вагу мають електровози - 50,7 \% та тепловози - 28,4 \%, термін експлуатації яких становить понад 40 років, а також вантажні вагони - 70,2 \%, термін експлуатації яких становить від 26 до 40 років. Високий ступінь зношення у 2019 р. - 79,0 \% мали пасажирські вагони, термін експлуатації яких перевищує 28 років [2]. Відповідно в умовах поширення пандемії та обмеження транспортної активності підприємства вантажного і пасажирського транспорту через дефіцит коштів не будуть мати змогу оновити свої основні засоби, особливо рухомий склад, що призведе до зниження рівня їхньої конкурентоспроможності, особливо в порівнянні 3 міжнародними перевізниками.

Наступною проблемою $є$ недостатній рівень розвитку транспортної інфраструктури. У 2019 р. в Індексі глобальної конкурентоспроможності Україна за фактором «Транспортна інфраструктура» посіла 59-е місце зі 141 країни світу. Зокрема, за якістю дорожньої інфраструктури - 114-е місце; ефективністю залізничного обслуговування - 34-е; ефективністю послуг повітряного транспорту - 101-е; ефективністю послуг морських портів - 78-е місце [1]. 
Проблеми функціонування транспортного сектору в умовах коронакризи можна поділити на такі, що виникають на макро- і мікрорівні. Серед основних проблем макрорівня можна виділити закриття кордонів, карантинні обмеження у сфері перевезення пасажирів, спад економічної і ділової активності, скорочення обсягів зовнішньої торгівлі, трансформація світової логістичної системи, погіршення кон'юнктури на експортних ринках, зниження купівельної спроможності населення, впровадження нових міжнародних екологічних вимог до транспорту тощо.

На мікрорівні виникають проблеми, пов'язані з відсутністю взаємодії і підтримки транспортних підприємств, особливо приватної форми власності, з боку державних органів влади й органів місцевого самоврядування; загроза банкрутства багатьох транспортних компаній; зменшення рівня зайнятих працівників на транспорті з причини його простою; зростання плинності кадрів, особливо серед водіїв далекобійників, що здійснюють внутрішні та міжнародні перевезення вантажів; збільшення кількості моряків, що працюють під іноземними прапорами через відсутність вітчизняного торговельного флоту; виникнення труднощів, пов'язаних із репатріацією моряків після закінчення терміну їх контракту і прибуттям на судно іноземної компанії у випадку зміни екіпажу; зростання транспортних витрат; відсутність у підприємств транспорту «фінансової подушки» тощо.

Відсутність необхідної підтримки підприємств транспорту унеможливлює здійснення ефективних заходів, спрямованих на відновлення вітчизняної економіки. Ще задовго до пандемії у прийнятій у 2018 р. Національній транспортній стратегії України на період до 2030 р. [12] вказувалось на необхідність розробки і впровадження нових принципів і підходів до формування та реалізації державної політики у транспортній галузі, зокрема, здійснення контролю за якістю виконання функцій, покладених на органи виконавчої влади. Подолання негативного впливу коронакризи на стан транспортного сектору України потребує суттєвої державної підтримки, особливо фінансової; внесення змін до чинного транспортного законодавства; надання різного роду преференцій; суттєвого зниження ставок по кредитах, кошти яких спрямовуються на оновлення рухомого складу; розвитку лізингу та державно-приватного партнерства.

Органи місцевого самоврядування в умовах пандемії особливу увагу повинні приділити сфері охорони здоров'я і розвитку комунального транспорту. В умовах обмеження кількості пасажирів у міському транспорті необхідно збільшувати кількість рухомого складу. Враховуючи дотаційний характер багатьох місцевих бюджетів та дефіцит місцевих фінансових ресурсів, дієвим виходом із ситуації, що склалася, є розвиток лізингових схем придбання транспортних засобів за рахунок зниження розміру лізингових платежів і можливості розвитку вторинного ринку лізингу.

Якщо до коронакризи найбільший обсяг перевезень вантажів на міжнародному транспортному ринку здійснювався морським транспортом, то на сьогоднішній день пріоритети змінилися в сторону залізничного транспорту. Враховуючи реалії України, саме залізничний транспорт займає провідні позиції в перевезенні вантажів різноманітних кон'юнктурних груп. Збільшенню транзитних перевезень буде сприяти розвиток технологій контрейлерних перевезень та розбудова відповідної інфраструктури для завантажувально-розвантажувальних робіт. Це дасть змогу покращити взаємодію залізничного й автомобільного транспорту, зменшити вартість і час транспортування вантажів, рівень навантаження на дорожньо-транспортну інфраструктуру, негативний вплив автотранспорту на довкілля.

3 метою підвищення якості транспортних послуг, завоювання нових сегментів внутрішнього і міжнародного транспортного ринку необхідно впроваджувати мережеві підходи до взаємодії різних видів транспорту. Останні передбачають створення різноманітних мережевих транспортних структур, а саме альянсів авіаційних, залізничних, 
ГАЛУЗЕВИЙ АСПЕКТ РОЗВИТКУ НАЦІОНАЛЬНОГО ГОСПОДАРСТВА

морських контейнерних перевізників, різноманітних транспортних кластерів та кластерних об'єднань, які передбачають консолідацію не тільки суб'єктів транспортного сектору, але й географічно та економічно пов'язаних з ними суб'єктів господарювання інших секторів національної економіки $[9 ; 10]$.

В умовах інформатизації суспільства, розвитку інформаційно-комунікаційних та цифрових технологій необхідно підвищувати рівень інформатизації і цифровізації транспортного сектору. Здійснення більшості операцій і видів бізнесу в онлайн-режимі обумовлює необхідність створення єдиного інформаційного простору, розвитку мережі транспортних супермаркетів, впровадження електронної логістики, підвищення рівня комп’ютеризації транспортних підприємств, використання хмарних технологій, штучного інтелекту з метою прискорення інтеграції транспортного сектору з іншими секторами економіки та підвищення рівня транспортної безпеки [8; 11].

Висновки і пропозиції. Враховуючи вищезазначене, в умовах пандемії особливо гостро $з$ одного боку відчувається пріоритетне значення транспортного сектору для розвитку економіки держави, з іншого залежність останнього від політичних, економічних, соціальних процесів, що відбуваються як на національному, так і на міжнародному рівнях. Подолання наслідків негативного впливу коронакризи на стан транспортного сектору України потребує суттєвої підтримки з боку як державних органів влади, так i органів місцевого самоврядування особливо в напряму розробки антикризових заходів. Останні повинні базуватися на вивченні передового досвіду країн світу в розробці і впровадженні заходів щодо відновлення ефективної роботи різних видів транспорту, що стане об'єктом подальших досліджень.

\section{Список використаних джерел}

1. Всесвітній економічний форум. URL: https://www.weforum.org.

2. Державна служба статистики України .URL: http://www.ukrstat.gov.ua.

3. Зварич Р., Тиш Т. Управління кризовими ситуаціями та лідерство в умовах коронакризи. Вісник Тернопільського національного економічного університету. 2020. Вип. 2. С. 135-147.

4. Кобилюх О. Я., Гірна О. Б., Гаєва Л. І. Ключові аспекти транспортної логістики в умовах пандемії Covid-19. Вчені записки ТНУ імені В. І. Вернадського. Серія: Економіка і управління. 2020. T. 31(70), № 4. С. 117-122.

5. Міжнародна асоціація повітряного транспорту. URL: https://www.iata.org.

6. Міжнародний союз автомобільного транспорту. URL: https://www.iru.org.

7. Міжнародний транспортний форум. URL: https://www.itf-oecd.org.

8. Никифорук О. І., Стасюк О. М., Чмирьова Л. Ю., Федяй Н. О. Цифровізація в транспортному секторі: тенденції та індикатори розвитку. Частина 1. Статистика України. 2019. № 3. С. 70-81. DOI:10.31767/su.3(86)2019.03.08.

9. Парубець О. М. Взаємозв'язок понять «мережа» і «мережева структура» як інтеграційних об'єднань підприємств транспорту. Ефективна економіка. 2014. № 3. URL: http://www.economy.nayka.com.ua.

10. Парубець О. М. Дослідження сутності мережевих об'єднань транспорту як економічної категорії. Технологический аудит и резервы производства. 2016. № 1/3 (27) С. 37-40. DOI: $10.15587 / 2312-8372.2016 .60598$.

11. Парубець О. М. Розробка методики оцінки рівня інформатизації транспортного сектору України як запорука його конкурентоспроможності. Технологический аудит и резервы производства. 2016. № 4/5 (30). С. 42-46. DOI: 10.15587/2312-8372.2016.76624.

12. Про схвалення Національної транспортної стратегії України на період до 2030 року : Розпорядження Кабінету Міністрів України від 30 травня 2018 p. № 430-p. URL: https://zakon.rada.gov.ua/laws/show/430-2018-\%D1\%80\#Text.

13. Chai S. Influence of New Coronavirus Epidemic on Service Industry and Countermeasures Firewood. Proceedings of the 2020 International Conference on Social Sciences and Big Data Application (ICSSBDA 2020). P. 251-253. URL: https://www.atlantis-press.com/proceedings/icssbda20/125945623.

14. Jenelius E., Mattsson L-G. Resilience of Transport Systems. URL: https://people.kth.se/ jenelius/JM_2020.pdf. 
15. Koehl A. Urban transport and COVID-19: challenges and prospects in low- and middleincome countries, Cities \& Health. 2020. DOI: 10.1080/23748834.2020.1791410.

\section{References}

1. World Economic Forum. (n.d.). https://www.weforum.org.

2. State Statistics Service of Ukraine. (n.d.). http://www.ukrstat.gov.ua.

3. Zvarych, R., Tysh, T. (2020). Upravlinnia kryzovymy sytuatsiiamy ta liderstvo v umovakh koronakryzy [Crisis management and leadership in a coronary crisis]. Herald of Ternopil National Economic University, (2), pp. 135-147.

4. Kobyliukh, O. Ia, Hirna, O. B., Haieva, L. I. (2020). Kliuchovi aspekty transportnoi lohistyky v umovakh pandemii Covid-19 [Key Aspects of Transport Logistics During the Pandemic COVID-19]. Scientific notes of Taurida National V.I. Vernadsky University Series: Economy and Management, 4(31(70)), pp. 117-122.

5. International Air Transport Association. (n.d.). https://www.iata.org.

6. World Road Transport Organisation. (n.d.). https://www.iru.org/ru.

7. International Transport Forum. (n.d.). https://www.itf-oecd.org.

8. Nykyforuk, O. I., Stasiuk, O. M., Chmyrova, L. Yu., Fediai, N. O. (2019). Tsyfrovizatsiia v transportnomu sektori: tendentsii ta indykatory rozvytku Chastyna 1 [Digitization in the Transport Sector: Development Trends and Indicators. Part 1]. Statistics of Ukraine, (3), pp. 70-81. DOI:10.31767/su.3(86)2019.03.08.

9. Parubets, O. M. (2014). Vzaiemozviazok poniat «merezha» i «merezheva struktura» yak intehratsiinykh obiednan pidpryiemstv transportu [Relationship of Terms "Network" and «Network Structure»" such as Integration Associations of Transport Enterprises]. Efektyvna ekonomika, (3). http://www.economy.nayka.com.ua.

10. Parubets, O. M. (2016). Doslidzhennia sutnosti merezhevykh obiednan transportu yak ekonomichnoi katehorii [Research of essence of network transport associations as an economic category]. Technology Audit and Production Reserves, 1(3(27)), pp. 37-40. DOI: 10.15587/23128372.2016 .60598 .

11. Parubets, O. M. (2016). Rozrobka metodyky otsinky rivnia informatyzatsii transportnoho sektoru Ukrainy yak zaporuka yoho konkurentospromozhnosti [Assessment method development of informatization level for transport sector in Ukraine as a guarantee of its competitiveness]. Technology Audit and Production Reserves, 4(5(30)), pp. 42-46. DOI: 10.15587/2312-8372.2016.76624.

12. Pro skhvalennia Natsionalnoi transportnoi stratehii Ukrainy na period do 2030 roku [On approval of the National Transport Strategy of Ukraine for the period up to 2030]. Order of the Cabinet of Ministers of Ukraine № 430-r (May 30, 2018). https://zakon.rada.gov.ua/laws/show/4302018-\%D1\%80\#Text.

13. Chai, S. (2020). Influence of New Coronavirus Epidemic on Service Industry and Countermeasures Firewood. Proceedings of the 2020 International Conference on Social Sciences and Big Data Application (ICSSBDA 2020) (pp. 251-253). https://www.atlantis-press.com/proceedings/icssbda-20/125945623.

14. Jenelius E., Mattsson L-G. (2020). Resilience of Transport Systems. https://people.kth.se/ jenelius/JM_2020.pdf.

15. Arnaud Koehl. (2020). Urban transport and COVID-19: challenges and prospects in low- and middle-income countries, Cities \& Health. DOI: 10.1080/23748834.2020.1791410.

|Парубець Олена Миколаївна - доктор економічних наук, професор, професор кафедри фінансів, банківської справи та страхування, Національний університет «Чернігівська політехніка» (вул. Шевченка, 95, м. Чернігів, 14035, Україна).

Парубец Елена Николаевна - доктор экономических наук, профессор, профессор кафедры финансов, банковского дела и страхования, Национальный университет «Черниговская политехника» (ул. Шевченко, 95, 14035 , г. Чернигов, Украина)

Parubets Olena - Doctor of Economic Sciences, Professor, Professor of Department of Finance, Banking and Insurance, Chernihiv Polytechnic National University (95 Shevchenka St., 14035, Chernihiv, Ukraine).

E-mail: olena.parubets@gmail.com

Orcid: https://orcid.org/0000-0001-5357-7581

Researcher ID: H-5503-2015

Парубець О. Дослідження впливу коронакризи на стан транспортного сектору України. Проблеми і перспективи економіки та управління. 2020. № 3(23). С. 26-32. 